\title{
Gerald Rannaud, Littérature et vérité. Stendhal
}

\section{Lise Sabourin}

\section{(2) OpenEdition}

\section{Journals}

\section{Édition électronique}

URL : http://journals.openedition.org/studifrancesi/34832

DOI : 10.4000/studifrancesi.34832

ISSN : 2427-5856

Éditeur

Rosenberg \& Sellier

\section{Édition imprimée}

Date de publication : 1 novembre 2005

Pagination : 429

ISSN : 0039-2944

\section{Référence électronique}

Lise Sabourin, «Gerald Rannaud, Littérature et vérité. Stendhal », Studi Francesi [En ligne], 146 (XLIX | II) | 2005, mis en ligne le 30 novembre 2015, consulté le 20 avril 2021. URL : http://

journals.openedition.org/studifrancesi/34832 ; DOI : https://doi.org/10.4000/studifrancesi.34832

Ce document a été généré automatiquement le 20 avril 2021.

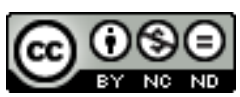

Studi Francesi è distribuita con Licenza Creative Commons Attribuzione - Non commerciale - Non opere derivate 4.0 Internazionale. 


\title{
Gerald Rannaud, Littérature et vérité. Stendhal
}

\author{
Lise Sabourin
}

\section{RÉFÉRENCE}

GERALD RANNAUD, Littérature et vérité. Stendhal, La Vie de Henry Brulard, in Genèses du «Je». Manuscrits et autobiographies, sous la direction de PHILIPPE LEJEUNE et CATHERINE VIOLLET, Paris, CNRS Éditions, 2000, pp. 15-34.

1 Dans un riche volume diachronique et comparatiste, cherchant à éclairer la théorie des genres par les études génétiques, en l'occurrence grâce aux avant-textes d'actes autobiographiques, Gérald Rannaud, responsable du programme d'étude du fond des manuscrits Stendhal à Grenoble, montre comment La Vie de Henry Brulard (dont il a assuré l'édition diplomatique Klincksieck 1997, en 3 volumes) par son inachèvement fixateur révèle la réflexion de Stendhal à partir de 1831 sur l'écriture narrative - de 1 'Histoire à soi, puis à une histoire. Le futur romancier tire les leçons de son expérience des biographies (Vie de Napoléon, de Rossini), mais aussi de l'explosion contemporaine du genre mémorialiste, enfin de son dépassement par l'autobiographie à l'anglaise diffusée par Philarète Chasles dans la Revue de Paris. 